\title{
Kuminaöljyn vaikutus perunaruttoon
}

\author{
Asko Hannukkala ${ }^{1)}$, Marjo Keskitalo ${ }^{1)}$, Jaana Laamanen ${ }^{1)}$ ja Marika Rastas ${ }^{2)}$ \\ ${ }^{1)}$ MTT, Maa-ja elintarviketalouden tutkimuskeskus, Kasvintuotannon tutkimus, 31600 Jokioinen \\ asko.hannukkala@mtt.fi,_marjo.keskitalo@mtt.fi \\ ${ }^{2)}$ Helsingin yliopisto, Soveltavan biologian laitos, PL 27, 00014 Helsingin yliopisto
}

\section{Johdanto}

Perunarutto, Phytophthora infestans (P. i.) on jokavuotinen perunantuotannon uhka, joka tavanomaisessa tuotannossa hallitaan nykyisin hyvin kemiallisten torjunta-aineiden avulla (Schepers 2001). Luomuperunaviljelyssä ei ole suoria torjuntakeinoja perunaruttoa vastaan, vaikka tauti aiheuttaa merkittäviä tuhoja useimpina vuosina. Uusi maasta leviävä entistä aikaisemmin alkava perunarutto on huomattavasti vaikeuttanut luomuperunan tuotantoa (Fry ym. 1993, Zwankhuizen ym. 1998, Hermansen ym. 2000).

Monien kasviperäisten yhdisteiden on osoitettu hidastavan tai ehkäisevän perunaruton kasvua. (Schmitt 1996, Blaeser ym. 1999). Kuminasta eristetyt öljyt ovat tehokkaita idunestoaineita, joita käytetään varastoitavalle perunalle. Kuminaöljykäsittely vähentää lisäksi monien varastotautien tuhoja (Bång 1995). Vuonna 1998 tehdyissä esikokeissa kuminaöljyn todettiin estävän perunaruton puhdasviljelmien kasvun ravintoalustalla ja tappavan taudinaiheuttajan nopeasti.

Tutkimuksen tavoitteena oli selvittää, onko kuminasta ja tillistä saatavien karvonipitoisten öljyjen avulla mahdollista ehkäistä tai viivyttää perunaruttoepidemian etenemistä ja millaisia ruiskuteväkevyyksiä peruna sietää vioittumatta.

\section{Aineisto ja menetelmät}

Kuminaöljyn tehokkuustestaukset ruttoa vastaan aloitettiin keväällä 2000 keinoalustalla (ruisagar) perunaruttosienen puhdasviljelmillä. Tehokkuustestauksia jatkettiin elävillä perunan lehdillä vuosina 2000 ja 2001. Noin 6-8 vk ikäisiä perunan lehtiä asetettiin Petri-maljoille ja käsiteltiin sumuttamalla niihin kuminaöljyjä ja P.i.-sienen itiöitä. Käsittelyjen jälkeen seurattiin silmävaraisesti oireiden ilmaantumista ja ruton etenemistä. Lehdistä tehtiin myös vioittumishavainnot, sillä vahvat kuminaöljypitoisuudet aiheuttavat polttovioituksia perunan lehtiin. Lehtitestien avulla selvitettiin sopivimpia kuminaöljypitoisuuksia, jotka tehosivat ruttoon, mutta eivät vioittaneet perunaa. Samalla tutkittiin, pitääkö käsittely tehdä ennen perunaruton itiöiden leviämistä kasviin vai tehoaako kuminaöljy ruttoon, vaikka ruiskutus vähän myöhästyisi. Kesällä 2001 vastaavanlaisia testejä tehtiin tilliöljyillä.

Erillisissä astiakokeissa kasvien vioittumisherkkyyttä selvitettiin kokonaisilla kasveilla kasvihuoneessa. Vuonna 2000 testattiin kuminaöljyjä ja vuonna 2001 tilliöljyjä. Vuonna 2000 tehtiin lisäksi pienimuotoisia esikokeita öljyjen tehosta perunaruttoa vastaan avomaalla. Laboratorio- ja kasvihuonetestausten tulokset rohkaisivat tehokkuustestausten jatkamiseen pelto-olosuhteissa.

Vuonna 2001 kenttäkokeessa verrattiin eri ruiskutusväkevyyksinä annettujen kuminasta ja tillistä puristettujen tai tislattujen öljyjen tehoa perunaruttoon. Sekä kumina että tilliöljystä valmistettiin rutontorjuntakokeisiin liuoksia, joiden väkevyys oli $1 \%, 2,5 \%, 5 \%$ ja $10 \%$. Ruiskuteliuos tehtiin 2,5\% mäntysuopaliuokseen, koska öljyt eivät sekoitu riittävän hyvin pelkkään veteen. Kokeessa oli täysin käsittelemätön verranne sekä kemiallinen rutontorjunta Shirlan- valmisteella $(0,4 \mathrm{1} / \mathrm{ha}$, tehoaine fluatsinami). Koemalli oli lohkoittain satunnaistettu koe. Lajikkeena oli rutonarka Bintje. Torjuntaruiskutukset aloitettiin kun NegFry- ruttoennusteen kynnysarvo, 130 ylittyi 12.7. 2001. Kaikki kumina- ja tilliöljy- sekä Shirlan- ruiskutukset uusittiin viikon välein. Kaikki koejäsenet ruiskutettiin 6 kertaa. Shirlan ruuduista hävitettiin varret kemiallisesti Reglonella viikon kuluttua viimeisestä ruttoruiskutuksesta.

Vuonna 2002 edellisvuoden tulosten perusteella kenttäkokeeseen valittiin tislattu ja puristettu kuminaöljy. Ruiskuteliuokset tehtiin 2,5\% mäntysuopaliuokseen. Ruiskutusväkevyys säädettiin niin, että tislatusta ja puristetusta öljystä tehtyjen ruiskuteliuosten karvonipitoisuus oli noin $5 \%$. Verranteina oli edellisvuoden tapaan käsittelemätön kontrolli ja kemiallinen kontrolli (Shirlan 0,4 1/ha). Ruiskutukset tehtiin 7 vrk välein. Lisäksi puristetulla kuminaöljyllä toteutettiin intensiivinen ruiskutusohjelma, jossa ensimmäisten ruttolaikkujen ilmaannuttua ruiskutukset tehtiin 3 vrk välein. Koe toteutettiin osaruutukokeena, jossa pääruutuna oli kaksi eri lajiketta, rutonarka Bintje ja melko kestävä Idole. Bintje käsiteltiin 5 kertaa ja Idole 6 kertaa. Intensiivisissä ohjelmissa Bintje sai 8 
ruiskutusta ja Idole 9 ruiskutusta. Rutonarka Bintje sai vähemmän ruiskutuksia, koska torjunta päätettiin lopettaa kun noin $50 \%$ lehtialasta oli tuhoutunut.

Ruton ilmaannuttua käsittelemättömiin koejäseniin havainnot ruton etenemisestä tehtiin 2-3 kertaa viikossa molempina koevuosina. Ruton ankaruus mitattiin arvioimalla silmävaraisesti ruton tuhoama lehtiala prosentteina. Ruttohavaintojen yhteydessä havainnoitiin lisäksi mahdolliset torjuntakäsittelyjen aiheuttamat vioitukset perunakasvustoissa. Kasvustohavaintojen perusteella laskettiin ruttoepidemian kulkua kuvaavia parametreja, kuten epidemian etenemiskäyrän muodostaman kuvion pinta-ala 'AUDPC' ja 'Apparent Infection Rate, AIR'. AIR on S-muotoisen taudin etenemiskäyrän logit muunnoksella oikaistun suoran kulmakerroin.

Sadonkorjuun jälkeen mukulasato lajiteltiin normaalin koekäytännön mukaan kokoluokkiin. Mukularutto määritettiin silmävaraisesti koeruutukohtaisesta 100 mukulan otoksesta noin kuukauden kuluttua nostosta. Sairaat ja terveet mukulat punnittiin, ja ruttoisten mukuloiden osuus laskettiin painoja kappaleprosentteina sadosta.

\section{Tulokset ja tulosten tarkastelu}

Useiden erityyppisten keinoalustatestausten perusteella kuminaöljyn todettiin estävän P.i.-sienen kasvun parhaimmillaan lähes kokonaan. Laboratorio- ja kasvihuonekokeiden perusteella kuminaöljyn, lähinnä siinä olevan karvonin, todettiin sopivina pitoisuuksina ehkäisevän perunaruton kasvua melko hyvin. Sopivat käyttöväkevyydet olivat $1-10 \%$ välillä. Väkevyydeltään yli $10 \%$ :n liuos aiheutti perunan lehtiin polttovioituksia ja laimentamaton kumina- ja tilliöljy tappoivat koko kasvin välittömästi käsittelyn jälkeen. Testien perusteella käsittely oli varminta tehdä ennen ruttoitiöiden leviämistä lehtiin.

Vuoden 2001 kenttäkokeessa ainoastaan Shirlan-ruiskutus viivästytti ruton ilmaantumista kasvustoon. Tilliöljyllä käsitellyissä koejäsenissä ensimmäiset rutto-oireet ilmaantuivat jopa aikaisemmin kuin käsittelemättömissä ruuduissa. Väkevimpien kuminaöljyjen ansiosta epidemian eteneminen hidastui selvästi käsittelemättömään kontrolliin verrattuna. (Taulukko 1).

Taulukko 1. Kumina- ja tilliöljykäsittelyjen vaikutus perunaruton kehitykseen ja mukulasatoon vuoden 2001 kenttäkokeessa Jokioisilla.

\begin{tabular}{lcccccccccc} 
käsittely & alku & $25 \%$ & Audpc & hsd & AIR & hsd & kokosato & hsd terve sato hsd \\
\hline Käsittelemätön & 12 & 30 & 3,4 & abc & 0,2 & a & 25,8 & ab & 25,4 & ab \\
Shirlan & 26 & EI & 0,3 & e & 0,0 & b & 33,4 & ab & 33,2 & a \\
Kuminaöljy 1 \% & 12 & 32 & 2,1 & bcd & 0,2 & a & 25,1 & b & 24,8 & b \\
Kuminaöljy 2,5 \% & 10 & 32 & 2,1 & abc & 0,3 & a & 23,5 & b & 23,2 & b \\
Kuminaöljy 5 \% & 12 & 34 & 1,2 & cde & 0,2 & a & 25,8 & ab & 25,4 & ab \\
Kuminaöljy 10\% 10 & 10 & 34 & 0,9 & ed & 0,2 & a & 26,3 & ab & 25,3 & ab \\
Tilliöljy 1 \% & 13 & 30 & 3,4 & ab & 0,3 & a & 22,3 & b & 21,9 & b \\
Tilliöljy 2,5 \% & 10 & 25 & 4,7 & a & 0,2 & a & 20,2 & b & 20,0 & b \\
Tilliöljy 5 \% & 11 & 24 & 4,5 & a & 0,2 & a & 18,2 & b & 17,6 & b \\
Tilliöljy 10 \% & 13 & 30 & 3,8 & ab & 0,3 & a & 21,4 & b & 21,1 & b \\
\hline
\end{tabular}

$\mathrm{Alku}=$ ensimmäinen ruttohavainto vrk ruiskutusten aloittamisesta

$25 \%=25 \%$ lehtialasta tuhoutunut vrk ruiskutusten aloittamisesta

Ruton etenemistä mittaava AUDPC oli pienempi kuminaöljykäsittelyissä, etenkin 5\% ja 10\% käyttöväkevyyksillä, kuin käsittelemättömässä ja tilliöljyillä käsitellyissä koeruuduissa. Kuminaöljykäsittelyillä ei päästy lähellekään kemiallisen torjunnan tehoa. Taudin etenemisnopeutta kuvaava 'Apparent infection rate' (AIR) oli jokseenkin sama kaikissa koejäsenissä, paitsi kemiallisessa torjunnassa (Taulukko 1). Shirlan-käsittelyä lukuun ottamatta millään käsittelyllä ei saatu merkittävästi lisäsatoa. Tilliöljykäsittelyissä terve kauppakelpoinen sato oli jopa alempi kuin kokonaan käsittelemättömissä koeruuduissa (Taulukko 1).

Vuoden 2002 kenttäkokeessa kuminaöljyt hidastivat ruton etenemistä epidemian alkuvaiheessa. 9.8 tehdyissä havainnoissa rutonarassa Bintje-lajikkeessa puristetulla öljyllä tehdyt käsittelyt tehosivat lähes yhtä hyvin ruttoon kuin kemiallinen käsittely (Kuva 1). Kestävämmässä Idole- lajikkeessa torjuntatehot olivat samansuuntaisia, mutta koejäsenten välisten suurten vaihtelujen takia erot eivät olleet tilastollisesti merkitseviä (Kuva 2).

14.8.2002 mennessä käsittelyjen väliset erot ruton tuhoamassa lehtialassa olivat tasoittuneet. Puristetulla kuminaöljyllä tehdyt käsittelyt olivat molemmissa lajikkeissa hidastaneet ruton etenemistä 
käsittelemättömään kontrolliin verrattuna, mutta vain Bintjessä erot olivat tilastollisesti merkitseviä (Taulukko 2).

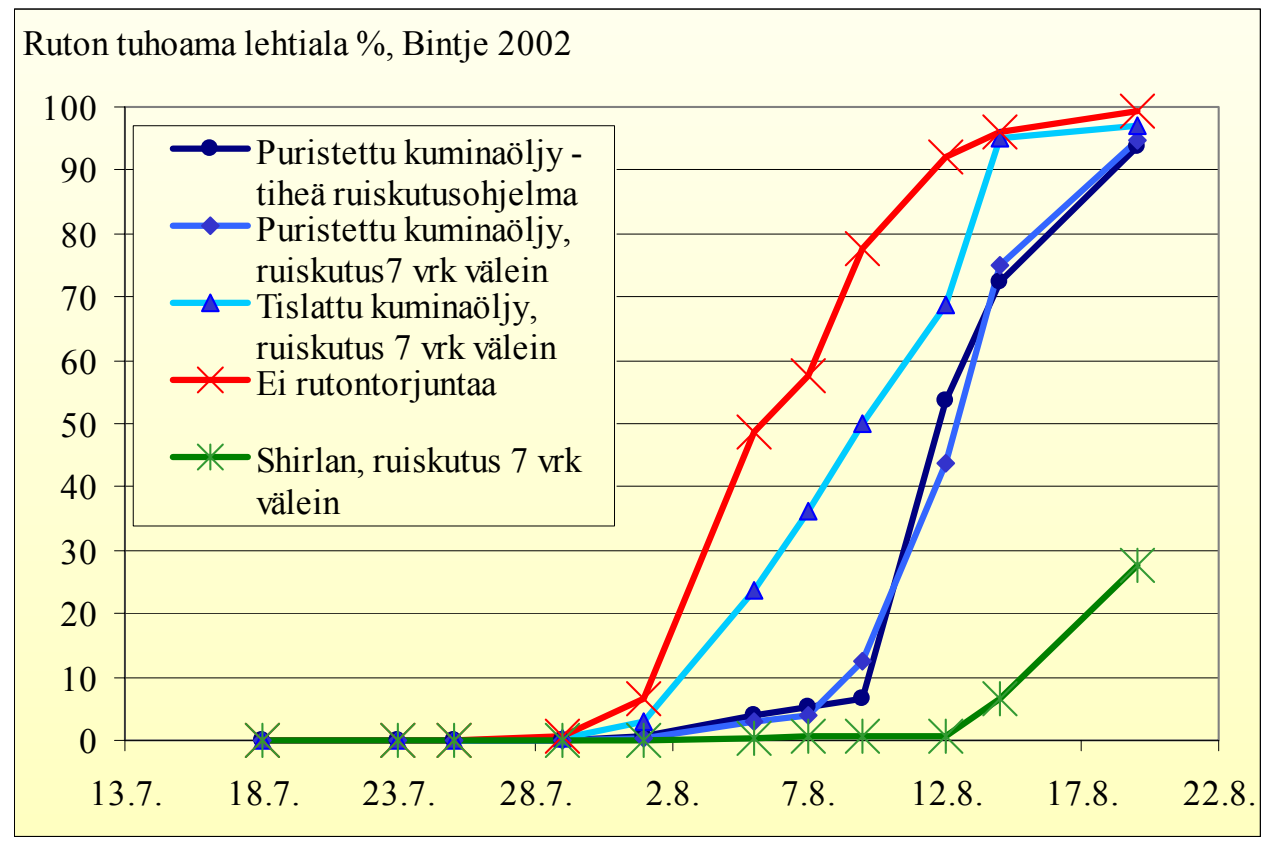

Kuva 1. Kuminaöljykäsittelyjen vaikutus perunaruton tuhoaman lehtialan kehittymiseen rutonarassa Bintjelajikkeessa kesällä 2002.

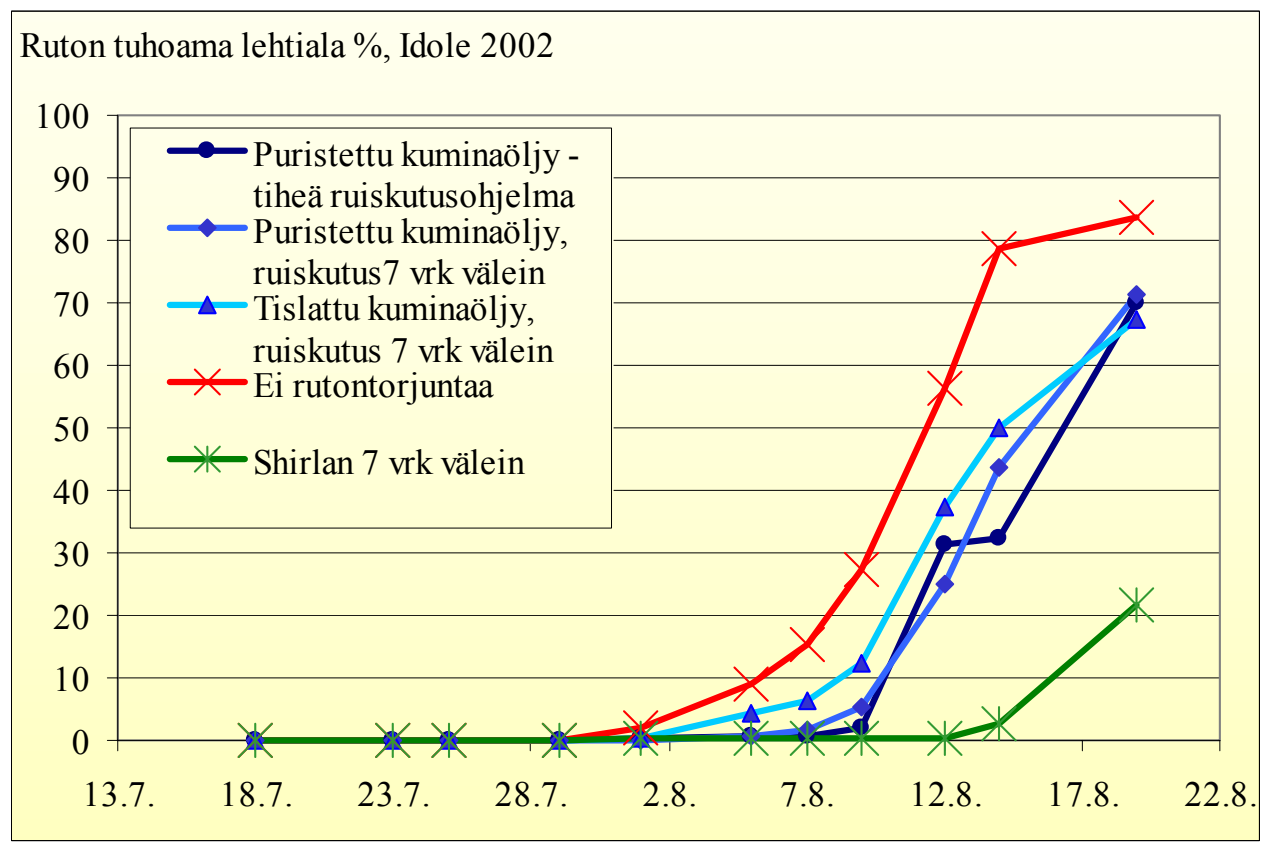

Kuva 2. Kuminaöljykäsittelyjen vaikutus perunaruton tuhoaman lehtialan kehittymiseen verraten kestävässä Idole-lajikkeessa kesällä 2002.

Kumpanakaan vuonna kuminaöljykäsittelyt eivät lisänneet mukulasatoa, vaikka lehtiruttoepidemian viivästymisen olisi olettanut parantavan satotasoa. Lehtiruton viivästyminen osui ajankohtaan, jolloin perunan kasvuedellytykset olivat hyvät. Kasvustoissa ei ollut näkyviä torjunta-ainevioituksia, mutta on mahdollista, että kuminaöljyruiskutukset tästä huolimatta stressasivat perunaa.

Vuoden 2001 ja 2002 tulosten perusteella oikein ajoitetut kuminaöljykäsittelyt voivat viivyttää perunaruttoepidemian alkamista. Tislattujen öljyjen teho oli huonompi kuin puristettujen öljyjen. Tislattu öljy koostuu lähinnä karvonista ja limoneenista. Puristetuissa öljyissä on lisäksi jäljellä komponentteja, joilla voi olla vaikutusta perunaruttoon tai kasvien indusoidun resistenssin 
ilmenemiseen. Olisikin hyödyllistä selvittää, onko näillä 'jäännöskomponenteilla' mahdollista parantaa kuminaöljyn tehoa perunaruttoa vastaan.

Taulukko 2. Kuminaöljykäsittelyjen vaikutus perunaruton kehitykseen ja satoon Bintje- ja Idole-lajikkeissa kesällä 2002. Mukularuttoa ei esiintynyt, joten satotulos on kauppakelpoisen sadon määrä.

\begin{tabular}{lcccccccc} 
Bintje & AIR & hsd & D98 & hsd & D148 & hsd & sato t/ha & hsd \\
\hline Käsittelemätön & 0,5 & a & 77,5 & a & 96,0 & a & 47,3 & a \\
Shirlan & 1,0 & a & 0,5 & c & 6,6 & d & 53,1 & a \\
Kumina, tislattu & 0,5 & a & 50,0 & ab & 95,0 & ab & 49,7 & a \\
Kumina, puristettu & 0,5 & a & 12,5 & bc & 75,0 & bc & 48,7 & a \\
Kumina intensiivi & 0,5 & a & 6,5 & c & 72,5 & c & 47,4 & a \\
\hline Idole & & & & & & & & \\
$\quad$ Käsittelemätön & 0,5 & a & 21,3 & a & 60,3 & a & 61,2 & a \\
Shirlan & 0,7 & a & 3,8 & a & 27,5 & a & 63,3 & a \\
Kumina, tislattu & 0,4 & a & 11,5 & a & 61,3 & a & 59,5 & a \\
Kumina, puristettu & 0,6 & a & 1,8 & a & 25,1 & a & 60,1 & a \\
Kumina intensiivi & 0,4 & a & 9,3 & a & 33,8 & a & 59,4 & a \\
\hline
\end{tabular}

D98 = lehtirutto \% 9.8. 2002

D148= lehtirutto \% 14.8.2002

Kuminaöljyn vaikutusmekanismia perunaruttoa vastaan ei tunneta. Tähänastisten kokemusten mukaan teho näyttää perustuvan pääasiassa polttovaikutukseen, ja tehon saavuttamiseksi öljyn on päästävä suoraan kontaktiin taudinaiheuttajan kanssa. Öljyt ovat erittäin nopeasti haihtuvia ja niiden teho saattaisi olla nykyistä parempi, mikäli haihtuvuutta voitaisiin hidastaa tavalla tai toisella. Yksi tutkimuksen haaste onkin öljyjen formulointi perunan lehtiin paremmin kiinnittyviksi.

\section{Kirjallisuus}

Bång, U. 1995. Natural plant extracts - control of fungal pathogens of potato. Proceedings of the Swedish crop protection conference: Svenska Växtskyddskonferensen: Jordbruk Skadedjur, växtsjukdomar och ogräs. $p$ 371-381.

Blaeser, P., Steiner, U., Lyr, H., Russell P.E., Dehne H.W. \& Sisler, H.D. 1999. Antifungal activity of plant extracts against potato late blight (Phytophthora infestans). Modern fungicides and antifungal compounds II Friedrichroda, Thuringia, Germany, 24th-29th May 1998. s. 491-499.

Fry, W.E., Goodwin, S.B., Dyer, A.T., Matuszak, J.M., Drenth, A., Tooley, F.W., Sujkowski, L.S., Koh, Y.J., Cohen, B.A., Spielman, L.J., Deahl, K.L., Inglis, D.A. \& Sandlan, K.P. 1993. Historical and recent migrations of Phytophthora infestans: chronology, pathways and implications. Plant Disease 77:653-661.

Hermansen, A., Hannukkala, A.O., Nærstad, R.H. \& Brurberg, M.B. 2000. Variation in populations of Phytophthora infestans in Finland and Norway: mating type, metalaxyl resistance and virulence pheotype. Plant Pathology 48:11-22.

Schepers, H.T.A.M. 2001. The development and control of Phytophthora infestans in Europe in 2000. Teoksessa: Westerdijk, C.E. \& Schepers, H.T.A.M. (toim.), Proceedings of the workshop on the European network for development of an integrated control strategy of potato late blight. Münich, Germany, 6-10 September 2000. PAV-Spoecial Report no 7. Lelystad, The Netherlands: Applied Reserarch for Arable Farming and Field Production of Vegetables. s. 7-10.

Schmitt, A. 1996. Plant extracts as pest and disease control agents. Atti convegno internazionale: Coltivazione e miglioramento di piante officinali, Trento, Italy, 23 giugno 1994 s. 265-272.

Zwankhuizen, M.J., Govers, F. \& Zadoks, J.C. 1998. Development of potato late blight epidemics: disease foci, disease gradients and infection sources. Phytopathology 88:754-763. 